\section{Studia \\ z Filologii Polskiej \\ i Słowiańskiej}

DOI: $10.11649 /$ sfps.2453
Studia z Filologii Polskiej i Słowiańskiej, 56

Warszawa 2021

Article No. 2453

Citation:

Јанковић, Ј. Д. (2021). Варијантност лингвистичке терминологије у србистици код именовања лексике преузете из словенских језика. Studia z Filologii Polskiej i Słowiańskiej, 56, Article 2453. https://doi.org/10.11649/sfps.2453

Janković, J. D. (2021). Varijantnost lingvističke terminologije u srbistici kod imenovanja leksike preuzete iz slovenskih jezika. Studia z Filologii Polskiej i Słowiańskiej, 56, Article 2453. https:// doi.org/10.11649/sfps.2453

\author{
Јелена Драгослав Јанковић \\ (Институт за српски језик САНУ, Београд)
}

\title{
Варијантност лингвистичке терминологије у србистици код именовања лексике преузете из словенских језика ${ }^{1}$
}

\section{Увод}

Српски језик се вековима богати лексиком из оних словенских језика са којима је долазио у директни или индиректни контакт. ${ }^{2}$ Управо је та лексика често била предмет научног истраживања, те су лингвисти посезали за терминолошким апаратом и употребљавали различите термине.

1 Овај рад финансирало је Министарство просвете, науке и технолошког развоја Републике Србије према Уговору број 451-03-68/2021-14/200174 који је склопљен са Институтом за српски језик САНУ.

2 Словенски језици су одиграли „битну улогу у обликовању савременог српског језика” (Ивић и др., 2004, с. 182). У формирању српског највише су се истакла три језика: старословенски односно црквенословенски, руски и чешки језик (Дабић, 1981, с. 7). О утицају словенских језика, посебно руског и чешког, на српски постоји богата литература, о томе детаљније в. Јанковић, 2017.

This is an Open Access article distributed under the terms of the Creative Commons Attribution 3.0 PL License (creativecommons.org/licenses/by/3.0/pl/), which permits redistribution, commercial and non-commercial, provided that the article is properly cited. (c) The Author(s) 2021.

Publisher: Institute of Slavic Studies, Polish Academy of Sciences

[Wydawca: Instytut Slawistyki Polskiej Akademii Nauk] 
Термини који се користе за именовање лексике преузете из словенских језика односе се на лексику која је уопштено словенског порекла, затим старословенског односно црквенословенског, рускословенског или српскословенског порекла, као и на лексику преузету из појединачних словенских језика: руског, чешког, пољског, словачког, словеначког, хрватског, бугарског, македонског, украјинског, белоруског језика или лужичких језика. У раду ће, такође, бити разматрано именовање лексике из времена славеносрпског периода, у предвуковском и вуковском периоду развоја српског књижевног језика, јер је та врста лексике маркирана управо својим словенским пореклом.

Лингвистички термини, који су предмет разматрања у раду, резултат су универбизације, тј. претварања вишечланих синтаксичких конструкција у једну реч творбеним средствима (Оташевић, 1997; Ћорић, 1991, с. 327). Термини добијени деривацијом (са суфиксом -изам), семантички су еквиваленти мотивисаних синтагматских формација: реч преузета из руског језика односно реч руског порекла односно руска реч> русизам (исти је принцип и код осталих термина).

Задатак рада јесте да се пружи детаљан преглед посведочености лингвистичких термина за именовање лексике преузете из словенских језика, на основу спроведене ексцерпције на референтним лингвистичким изворима, а у циљу уочавања терминолошких проблема, не само у српском, већ и у ширем словенском контексту.

\section{2. Преглед лингвистичких термина}

Лингвистички термини ексцерпирани су у првом реду из енциклопедијских речника лингвистичке терминологије српског језика. Укупно пет речника доноси термине који се односе на словенске језике и историју српског књижевног језика а самим тим и термине којима се именује лексика преузета из тих језика.

3 Табеларни приказ ексцерпираних термина дат је на платформи Academia: https:// isj-sanu.academia.edu/JelenaJanković/Conference-Presentations (Јанковић, б.д.).

4 у Граматичкој терминологија А. Белића и С. Ившића (1932), речнику термина израђеног при Терминолошкој комисији на основу грађе из тадашњих средњошколских књига у циљу уједначавања школске терминологије, обрађени су једино називи за 
1. У лингвистичком енциклопедијском лексикону Српскохрватски језик (ELSHJ, 1972), једином речнику ове врсте у србистици, обрађено је укупно 18 термина којима се обележава лексика страног порекла, од тога само 4 су одреднице које се односе на порекло из словенских језика. ${ }^{5}$ То су: бохемизам и чехизам ,jezička osobina karakteristična za češki jezik; češki izraz u nekom drugom jeziku, pozajmljenica iz češkog jezika", дефиниција je дата у одредници бохемизам, док се други термин сматра синонимом; ${ }^{6}$ русизам „osobine ruskog jezika u nekom drugom jeziku” и полонизам „reč ili izraz iz poljskog jezika u nekom drugom jeziku”. Поред одредница чешки, руски и польки језик, обрађене су и словачки, словеначки (словенски), бугарски, македонски и белоруски језик, међутим у лексикону нису дати појмови којима би се означила лексика преузета из тих језика.

У лексикону се нашла и одредница славенске (словенске) туђице (дате у облику множине!) с дефиницијом да су то „reči koje su u srpskohrvatski književni jezik došle iz drugih slovenskih jezika” и с појашњењем да те речи могу бити бохемизми односно речи узете из чешког језика или русизми односно речи узете из руског језика. 7 Посебно је интересантно то што је тим термином сугерисано да је варијанта са - $a$ - надређени појам, иако је одредница словенски (славенски) језици наведена обрнутим редоследом, тј. предност је дата облику са -о-, а што се види и по начину обраде (дефиниција је наведена уз термин словенски језици).

У лексикону су, такође, дати термини: старословенски (старославенски) језик, дефинисан као први словенски књижевни језик; староцрквенословенски језик „jedan od naziva za staroslovenski jezik”; uрк-

словенске језике. Речници који не доносе термине из те области су: Кембричка енииклопедија језика (1995) и Енииклопедијски речник модерне лингвистике (1999) Д. Кристала, као и Речник лингвистичких термина (2001) Н. Ђокић.

5 У питању су следећи термини: американизам, англицизам, арабизам, аустријаиизам, бохемизам, чехизам, галицизам, германизам, грецизам, хунгаризам, латинизам, мађаризам, оријентализам, полонизам, романизам, русизам, талијанизам и туриизам. Поред ових термина, у лексикону су обрађени и термини: варваризам, туђица, туђа реч, позајмъеница и позајмъена реч.

6 Другачији је, пак, поступак обраде термина хунгаризам и мађаризам. Дефиниција, практично иста, дата је на оба места, с тим што се на крају одреднице хунгаризам упућује на мађаризам, док се у одредници мађаризам не помиње други термин хунгаризам.

7 А. Милановић сматра да је то „из више разлога неочекивано терминолошко решење” (Милановић, 2005, с. 324) и да осим тог термина, у речнику нема одреднице словенизам (славенизам) нити словенска позајмленииа (Милановић, 2003, с. 297). 
венословенски (ирквенославенски) језик „staroslovenski jezik u crkvenoj upotrebi”, са додатном напоменом да је староирквенословенски језик реконструисан на основу језика Ћирилових и Методијевих превода, а да је новоцрквенословенски језик старословенски језик руске редакције; затим рускословенски или рускоирквени језик, синоним руска редакција староирквенословенскога језика; српскословенски (српскославенски) језик, са два синонима: старословенски језик српске редакције (s.v. srpska redakcija) и стари uрквенословенски језик. ${ }^{8}$ За књижевни језик Срба настао у другој половини XVIII века, у лексикону дат је термин славеносрпски (славеносербски) језик за који је наведено да је настао „mešanjem ruskocrkvenoslovenskog jezika i jezika srpskog građanskog društva". ${ }^{9}$ У лексикону нису дати појмови којима би се означила лексика пореклом из тих језика.

2. Двотомни Енциклопедијски рјечник лингвистичких назива загребачког лингвисте P. Симеона (Simeon, 1969) замишљен је као речник свеукупне лингвистичко-филолошке терминологије. У њему има укупно 17 термина којима се именује лексика преузета из словенских језика. Српско-хрватски лингвистички термини дати су са детаљним дефиницијама и тумачењима, као и са еквивалентима из 7 језика.

Термини којима се именује лексика словенског порекла су: славизам „jez. element, riječ, izraz, konstrukcija, frazeološki skup preuzet iz kojeg slavenskoga jezika u neki neslavenski jezik"; славенизам синоним за славизам, „slavenski element u neslavenskom jeziku”, уп. са термином славенски језици „linguae slavae vel slavicae”; словенизам синоним за славизам, „tamo gdje se za Slaven kaže Sloven”, уп. словенски језик синоним за славенски језик, „slavicus, Slavisch”, уз напомену: „орс́enito se i danas u tom značenju upotrebljava u Srba”; славина „riječ iz slavenskih jezika”, уп. славина „slavenski jezik (bilo koji)".

Термини којима се именује лексика преузета из старословенског или црквенословенског језика су: старославенизам „crkvenoslavenski element

8 у лексикону дата је и одредница хрватска редакција (рецензија) у којој се наводи да се она односи на рецензију старословенских текстова.

9 Тај термин се значењски подудара са називом славенороссийский язык, који се употребљава код појединих руских аутора XVIII века. О називу тог језика в. Младеновић, 1989, с. 77, нап. 3, 94-100, 2008, с. 205, нап. 8. 
ili izraz, crkvenoslavenska riječ”, уп. старославенски језик „najstariji knjiž. slavenski jezik", стари ирквенославенски језик синоним за ирквенославенски, словенски језик „slovenicus”, славенски језик „іsto što i staroslovjenski, tj. stari crkvenoslavenski jezik koji se do danas sačuvao u crkvi”; славенизам синоним за старославенизам, ирквенославенизам (sic! ирквенославизам), палеославенизам, ${ }^{10}$ "staroslavenski ili crkvenoslavenski element ili obilježje u kojemu suvremenom slavenskom jeziku”, као и „stsl. ili stcsl. riječ, oblik, izraz, frazeološki skup, konstrukcija, koji su iz stsl. i stcsl. ušli u knjiž. jezik uglavnom onih slav. naroda u kojih je stsl. ili stcsl. bio nekada jezik ne samo liturgije nego i književnosti, obogativši znatno njihov leksik i proširivši njihove stilističke mogućnosti”; ирквенославизам синоним за славенизам, „crkvenoslavenski element, crkvenoslavenski izraz”, уп. ирквенославенски језик; славизам синоним за славенизам.

Термини којима се именује лексика преузета из других словенских језика су: кроатизам „hrvatska riječ, izraz, konstrukcija ili izreka preuzeta u doslovnom, promijenjenom ili prevedenom obliku u koji drugi jezik; osobina (samo) hrvatskoga jezika”, уп. хрватски језик; словенизам „jezični element (glas, riječ, oblik, konstrukcija) karakterističan za slovenski jezik, koji se upotrebljava u nekom drugom jeziku ili njegovu dijalektu”, уп. словенски језик и словеначки језик; булгаризам ,jezični element preuzet iz bugarskog ili staroslavenskog jezika”, уп. бугарски језик; ${ }^{11}$ бохемизам ,jezični element (riječ ili izraz) preuzet iz češkoga u koji drugi jezik”; иехизам „с̌eška riječ, izraz ili jezična osobina u drugomu kojem jeziku”, уп. чешки језик; полони$\boldsymbol{з a \boldsymbol { M }}$,jezični element ili izraz uzet u neki drugi jezik iz poljskoga jezika”, уп. пољски језик; словацизам „slovački jezični element, riječ ili izraz, preuzet u koji drugi jezik", уп. словачки језик; русизам „jezični element (riječ, izraz, konstrukcija) preuzet iz ruskoga jezika u koji drugi jezik”, уп. руски језик; украјинизам „ukrajinski element, riječ ili izraz u kojem drugom jeziku, npr. ruskom, poljskom i dr.”, уп. украјински језик.

Поред ових термина, у речнику обрађен је и термин македонски/ мацедонски језик, али није дат термин којим се именује лексика македонског порекла. Такође, обрађени су термини за редакције старословенског језика: рускославенски и српскославенски/српскослов( $)$ енски језик.

10 Термини ирквенославенизам и палеославенизам није обрађени у Симеоновом речнику.

11 Уп. још и термине булгарист, булгаристички, булгаристика у Симеоновом речнику. 
3. Школски речник језичких термина и појмова Ј. Вуксановића (ШРЈТП, 2003) настао је због потребе за уједначавањем терминологије и систематиком појмова у области српског језика и српске граматике. У обради термина истакнуто је њихово порекло, дат је опис и значење, дефиниција и пример уз евентуалне допунске информације. Из тог речника ексцерпирано је укупно 2 термина: русизам „реч или језичка конструкција преузета из руског језика или сачињена према том језику, а не слаже се са системом језика у коме је то сачињено" и кроатизам „особина хрватског језика, посебно у лексици”.

Поред тих термина, наведени су називи: словенски језици; старословенски језик „први писани (никад није био говорни!) књижевни језик свих словенских народа настао у другој половини IX века. [...] У науци је он познат и под називом староцрквенословенски језик"; ирквенословенски језик „овим језиком се данас назива богослужбени језик православних и унијата (припадника православне вере који признају папску власт, гркокатолици) Словена: Срба, Руса, Бугара, Чеха, Словака. У науци се он назива још и новоцрквенословенски језик. [...] Назив ирквенословенски новијег је датума (од 17. века)"; српскословенски језик,,језик српске редакиије или рецензије старословенског језика [...] Назива се и србулькки језик”; рускословенски језик ,језик руске редакције или рецензије старословенског језика"; руски језик; славеносербски/славеносрпски/славјански језик, међутим нису дати појмови којима би се означила лексика пореклом из тих језика.

4. Новији терминолошки речник М. Радовић Тешић Граматички и лингвистички појмовник (ГЛП, 2011) обухвата основну терминологију основношколског и средњошколског програма српског језика и служи ученицима и студентима као систематизовано помоћно средство за усвајање градива из области српског језика. У њему обрађено је 5 термина којима се именује лексика преузета из словенских језика: ирквенословенизам „реч из црквенословенског језика употребљена у књижевном језику”, уп. ирквенословенски језик „старословенски језик (измењен у локалној средини) у црквеној употреби”; русизам „позајмљеница, реч или израз из руског језика”; бохемизам „позајмљеница, реч или израз, конструкција преузета из чешког језика"; кроатизам „позајмљеница (реч или израз) из хрватског језика”; славенизам „реч или израз карактеристичан за текстове старе српске књижевности писане једном од варијаната књижевног језика 
пре Вукове реформе - српскословенским, рускословенским или славеносрпским језиком”; уп. славеносрпски (славеносербски) језик „књижевни језик Срба у Војводини настао у другој половини 18. века мешавином рускословенског, народног српског и српскословенског језика".

У терминолошком појмовнику обрађени су још и термини: словенски језици, старословенски, староирквенословенски језик (синоним за старословенски језик), редакиија старословенског језика, српска редакиија, српскословенски и рускословенски језик, али нису дати појмови којима би се означила лексика пореклом из тих језика.

5. Slovník slovanské lingvistické terminologie (SSLT, 1977-1979) вишејезични је словенски лингвистички терминолошки речник, плод заједничког општесловенског пројекта Терминолошке комисије при Међународном комитету слависта у другој половини прошлога века у Прагу. ${ }^{12}$ У њему дати су репрезентативни лингвистички термини еквивалентни терминима из различитих словенских језика, без описа значења терминолошких јединица. Српски термини презентовани су у речнику у оквиру српско-хрватског односно хрватско-српског речничког дела. ${ }^{13}$

У том вишејезичном терминолошком појмовнику дато је укупно 200 словенских терминолошких јединица, ${ }^{14}$ од тога је 16 српских: славизам, ирквенословенизам, србизам, кроатизам (хрватизам), словенизам, бугаризам, македонизам, русизам, полонизам, бохемизам (чехизам), словакизам, украјинизам, б(j)елорусизам и сорабизам.

6. У Правопису српскога језика (Пешикан и др., 2010) прописани су следећи термини: славизам и словенизам „реч из старословенског и уопште традиционалног словенског језичког наслеђа” (с. 453), уп. старословен-

12 В. Јовановић (Јовановић, 2017) спровео је анализу српских термина у том речнику из угла савременог стања српске лингвистичке терминологије.

13 Материјал српско-хрватског односно хрватско-српског језика штампан је ћирилицом, док је латиница употребљена само за термине који су са хрватског говорног подручја. Уколико је термин својствен српском језичком стандарду, он је обележен знаком у облику троугла $(\boldsymbol{\Delta})$. Ексцерпирани термини се углавном подударају у српском и хрватском језику, осим у случају термина срп. ирквенословенизам - хрв. ирквенославенизам, срп. ирквенословенски језик - хрв. ирквенославенски језик, срп. старословенски језик - хрв. старославенски језик и срп. словенски језик-хрв. славенски језик.

14 У речнику дати су и термини сербокроатизам, европеизам, балканизам, палеославизам и панонизам, који у овом раду нису подвргнути анализи. 
ски, ирквенословенски (с. 460); русизам (с. 441); бохемизам „позајмица из чешког језика” (с. 273); полонизам „позајмица из пољског језика” (с. 415) и кроатизам (с. 353).

7. Термине којима се именује лексика преузета из словенских језика употребљавају лингвисти у својим монографијама и научним чланцима.

Речи преузете из других словенских језика најчешће се називају словенизмима (Брборић, 1996, с. 34; Матијашевић, 1996b, с. 154; Стевановић, 1987, сс. 74-75), ређе славенизмима („словенске речи у словенској средини"; Матијашевић, 1996b, с. 156) или славизмима (Дабић, 1981, с. 13). Појам славизам често се односи за словенске речи у несловенским језицима, нпр. румунски/мађарски/албански славизам (в. Лома, 1999, с. 102; Сикимић, 1997, с. 246).

Речи пореклом из старословенског односно црквенословенског језика се обележавају терминима: старословенизам (Грицкат, 1969, с. 24; Ивић и др., 2004, с. 182), ирквенословенизам (Милановић, 2018, с. 232; Станковић, 1996, сс. 377, 381), ретко црквенославенизам (в. Маројевић, 2002-2003, с. 214, 2007, с. 210, 2008, с. 190) и ирквенославизам (в. Грицкат, 1985, с. 61) и бројне двочлане терминолошке синтагме, као што су: староирквенословенска ријеч (Skok, 1971-1974), ирквенословенска лексика (Стијовић, 1992, с. 49) итд.

Лексика из српскословенског односно српске редакције црквенословенског језика означава се терминима: српскословенизам (Грицкат, 1963-1964, с. 228; Милановић, 2017, с. 317) и српскославенизам (Радовић Тешић, 2009, с. 81).

За лексику из рускословенског односно руске редакције црквенословенског језика у оптицају је више термина: рускословенизам (Младеновић, 1989, с. 56), славенорусизам (Радовић Тешић, 2009, с. 81; Терзић, 2003), славенизам, рускославенизам (Радовић Тешић, 2009, с. 81), словенизам (Дабић, 1981, сс. 9, 12), русизам славеноруског порекла (Терзић, 2003), ирквенорусизам и бројне синтагматске конструкције: ирквеноруска реч, реч ирквеноруског порекла, реч ирквенословенско-руског порекла (Стијовић, 1992, сс. 47-49).

Термини за означавање лексике из тог језика изведени су из различитих термина којим се именује рускословенски језик. Иако је назив рускословенски језик уобичајен, у србистичкој литератури се употребљава више различитих термина: славенски или славјански, ирквенословенски, 
новочрквенословенски, рускочрквенословенски језик и др. Назив славенски/ славјански језик ${ }^{15}$ користио се у XVIII и у првој половини XIX века код Срба и означавао је „руски црквени језик”. ${ }^{16}$ Касније је термин ирквенословенски језик заменио старији назив славенски језик, „и то пре свега у црквеним и научним круговима, а у употребу је уведен такође и термин рускословенски језик (што је пандан термину српскословенски језик) који се јавља најчешће у научној литератури" (Младеновић, 2008, с. 250).

У стручној литератури усталио се термин русизам. Он се односи на реч преузету из руског књижевног и народног језика или на ону која је начињена по руском узору. Такође, под русизмом подразумева се и реч која је у руском а несловенског је порекла или која је по пореклу из неког другог словенског језика, па је у том случају руски језик посредник. ${ }^{17}$

У славистици је општеприхваћено мишљење да је руски књижевни језик амалгам руског народног говора и црквенословенског језика руске редакције. Из тог разлога, под термином русизми подразумевају се речи или чисто руске провенијенције (чисти русизми) или из руске редакције црквенословенског језика. Обе врсте русизама „функционишу као један комуникациони систем, и стога је умесно такву језичку грађу, пренесену у српски књижевни језик, назвати термином русизми" (Терзић, 2003, с. 205). ${ }^{18}$

Б. Терзић разликују русизме у ужем значењу, тзв. иисти русизми речи преузете из руског народног језика и русизме у ширем значењу речи из рускословенског, „славенизми руског типа” (Терзић, 1999, с. 269, 2003). У србистици често се употребљава термин совјетизам за русизме совјетске епохе - речи које су добијене након октобарске револуције

15 Преузимање славенског односно славјанског језика започето је у трећој деценији XVIII века, те је тако смењена дотадашња (преко пет векова стара) српска редакција старословенског језика, која се употребљавала паралелно са српским народним језиком.

16 Назив славенски језик употребљавао је и Вук Стефановић Караџић. Он је у свом раду Главне разлике између данаштега Славенскога и Српскога језика (1826) системски изложио најзначајније разлике између тадашњег језика славенскога (језика из црквених књига) и српског (народног) језика. О вишезначности назива славенски језик код Вука в. детаљније у раду Б. Чигоје (Чигоја, 1988).

17 Дефиницију русизма, засновану на теорији трансфера у контактологији, дали су Ј. Ајдуковић (Ајдуковић, 1997, с. 18, 1999, сс. 123-124) и П. Пипер (Пипер, 1999, с. 130).

18 Према речима Б. Терзића, „руски и рускословенски елементи, заступљени у језичкој грађи нашег XVIII и XIX века, представљају основицу онога што ми данас називамо русизмима" (Терзић, 1999, с. 172). 
(Терзић, 2003, с. 213; Тошовић, 1981, с. 35). Ј. Матијашевић ту врсту лексике обележава термином млади русизми (Матијашевић, 1996а, с. 367).

У србистици се користе два термина бохемизми или (ређе) чехизми за обележавање речи које су преузете из чешког језика или које су начињене по чешким узорима. ${ }^{19}$ Термин бохемизам изведен је из латинског назива за Чешку Bohemia „земља Боја”, од античког Boiohaemum. „Боји су били келтско племе, први историјски познати становници Чешке и Баварске у 3. и 2. веку н. е." (Копривица, 2008, с. 371).

У српском језику мали је број речи преузетих из пољског језика. Оне се у србистичкој литератури увек означавају термином полонизам (Брборић, 1996, с. 34; Дабић, 1981, с. 13). Термин је изведен од латинског назива за Пољску Polonia.

Од осталих термина, у србистичкој литератури употребљавају се термини: кроатизам (Брборић, 1996, с. 34; Дешић, 2017; термин изведен од лат. Croata „Хрват”), бугаризам (Брборић, 1996, с. 34; Дабић, 1981, с. 13) и словакизам (Брборић, 1996, с. 34).

На крају ваља поменути још један термин славенизам, ${ }^{20}$ који је уобичајен („одомаћен”; Чигоја, 2005, с. 315) у многим србистичким публикацијама, а који је терминолошки неуједначен и коегзистира са другим терминима. Славенизми су били „саставни део славеносрпског књижевног језика, који је више деценија био у употреби код Срба (у другој половини XVIII и у првој половини XIX века)" (Младеновић, 2008, с. 346), у предвуковском и вуковском периоду развоја српског књижевног језика. ${ }^{21}$ Сам термин је сачињен „по називу славенски језик како се раније називала руска редакција старословенског језика, руски црквени језик, и то у руској средини, што је преузето и код Срба" (Младеновић, 2008, с. 346).

Како у руској литератури постоји подела на славенизме и русизме, „где се ради о разграничавању лексике из црквенословенског и домаћег, то

19 Бохемизмима се не сматрају „оне речи које су се прошириле из чешког у друге словенске језике у давној прошлости” и које су на крају постале део општесловенског лексичког фонда (детаљније о томе в. Копривица, 2008, с. 372).

20 О том термину писали су: Зорић, 2013; Јанковић, 2017, сс. 77-80, 2019; Чигоја, 2005.

21 Године 2017. објављена је Огледна свеска Речника славеносрпског језика, у којој су славенизми дефинисани као „специфичан лексички слој који је представљао врсту симбола овог језичког типа” и по речима аутора, „обухватају значајан део грађе” (Бјелаковић и др., 2017, сс. 19, 24). У свесци има око 1000 лексема, а од тога је 451 лексема квалификована као славенизам. О томе детаљније в. Јанковић, 2019. 
јест руског наслеђа" (Стијовић, 1992, с. 14, нап. 2), у србистици поједини под појмом славенизам подразумевају искључиво форме пореклом из црквенословенског језика руске редакције. То чине Н. Толстој и Б. Унбегаун (Зорић, 2013, с. 813; Стијовић, 1992, с. 13, нап. 2) и Б. Дабић, који разликује у једном свом раду славјанизме (< славјански језик) и русизме, а у другом словенизме и русизме (Дабић, 1981, сс. 9, 12, 1984, с. 51). Б. Чигоја сматра да се под термином славјанизам обично „подразумевају језичке црте рускословенског језика” (Чигоја, 2005, с. 315). С. Стијовић истиче да је код нас, за разлику код Руса, „друга ситуација, пошто је наш језик, поред старокњижевне традиције обеју редакција (српске и руске), утицао и руски, те је нормално да појам 'славенизам' садржи и руску компоненту” (Стијовић, 1992, сс. 13-14, нап. 2).

А. Младеновић је знатно утицао на нормирање термина српскословенски, рускословенски и славеносрпски језик, као и термина славенизам, под којим он подразумева „речи које су словенског порекла (најчешће рускословенског и руског, или, у мањој мери, и српскословенског), а не припадају српском народном језику" (Младеновић, 2008, с. 346). Данас је у србистици општеприхваћена управо та дефиниција, а С. Стијовић jу је потврдио на Његошевом корпусу. Наиме, С. Стијовић је на основу спроведене анализе језика П. П. Његоша (1813-1851), који се у својим делима обилато служио славенизмима, дошао до дефинције, да су славенизми речи и особине које припадају српскословенској, ${ }^{22}$ рускословенској, ${ }^{23}$ заједничкој црквенословенској и руској лексици, укључујући и разне позајмљенице у овим језицима, а такође и хибридне творевине, то јест облици који садрже особине и црквенословенског, без обзира на редакције, или руског, и нашег језика (Стијовић, 1992, с. 13). Наиме, у славеносрпском периоду приликом адаптације рускословенске и руске лексике стварали су се хибриди, мешовите форме, тзв. славеносрбизми ${ }^{24}$

22 Б. Терзић (Терзић, 1999, с. 266), приликом анализе лексике у Житију Г. Зелића (1823), помиње славенизме српскословенске провенијенције. Б. Чигоја (Чигоја, 2005, с. 318), наводећи С. Стијовића, такође користи термин српскословенски славенизам.

${ }^{23}$ Б. Чигоја (Чигоја, 2005, сс. 318-319) те речи назива рускословенски и руски славенизми.

${ }^{24}$ Најпрецизнији опис тог термина даје А. Милановић. Наиме, у хибридним речима славеносрпског периода налазили су се елементи различитих језика: српског народног и рускословенског (руског), српског народног и српскословенског, или пак рускословенског (руског) и српскословенског језика (Милановић, 2005, с. 323). 
(Милановић, 2005; Младеновић, 1989, сс. 56, 57; Стијовић, 1992, сс. 22, 37; о славеносрбизмима код Вука, в. Стевановић, 1987, сс. 62-90). Б. Брборић користи термин старословенски хибриди односно хибридни славенизми (Брборић, 1996, с. 35). У србистици се среће и термин посрбица као српски еквивалент за реч страног порекла у славеносрпском периоду (Милановић, 2004, с. 249, 2018, с. 231).

У савременој литератури се под славенизмима, такође, подразумевају речи из црквенословенског језика и његових редакција (Брборић, 1996, с. 34) или речи само из рускословенског и руског језика (П. Ивић; Љ. Суботић; в. Зорић, 2013, сс. 814, 815). У употреби су и термини: словенизам - Б. Станковић (Станковић, 1996, сс. 377, 381) под њим подразумева речи из црквенословенскг, рускословенског или руског језика и славизам - М. Пешикан (Пешикан, 1985, с. 274) њиме обухвата „старословенизме” и русизме.

Засигурно овде није представљен целокупан списак термина, јер за такав подухват неопходно би било дубље заћи у србистичке изворе, што би превазишло оквире и могућности једног рада.

\section{3. Анализа лингвистичких термина и закључци}

Сагледавањем целокупног ексцерпираног материјала, уочавају се терминолошки проблеми који се тичу варијантности и неуједначености лингвистичких термина код именовања лексике преузете из словенских језика. Проблеми се односе на постојање дублетних форми, ${ }^{25}$ синонимних и хомонимних облика, као и на дефинисање лингвистичких термина из те области.

Варијантност лингвистичких термина огледа се у пре свега у појави дублета у фонетском лику термина. Основа слов- алтернира са латинизованим обликом слав- у бројним примерима: словенизам - славенизам, старословенизам - старославенизам, ирквенословенизам - ирквенославенизам, српскословенизам - српскославенизам, рускословенизам - рускославенизам. Исти проблем јавља се и код именовања језика из којих су изведени ти термини (о тој појави писао је А. Милановић, 2003, сс. 298-299).

25 Два лика једне исте речи с истим значењем, који се међусобно разликују у најмање једном делу назива се дублет (ELSHJ, 1972, с. 77). У раду се разматрају фонетски и творбени дублети, док се за лексички дублет користи термин синоним. 
Творбених дублета има мање, уп. славизам - славенизам, словацизам - словакизам, булгаризам - бугаризам.

Појава синонима и хомонима је изузетно честа код термина из ове области.

Међу синонимима присутни су и дублетни облици, фонетски и творбени, а највише их има код означавања лексике преузете из рускословенског језика: рускословенизам, рускославенизам, славенорусизам, славенизам, словенизам, ирквенорусизам; из старословенског језика: старословенизам, старославенизам, славенизам, славизам; из црквенословенског језика: ирквенословенизам, ирквенославенизам, ирквенославизам; из словенских језика: славизам, славенизам, словенизам; ${ }^{26}$ из чешког језика: бохемизам, чехизам итд. Посебно је у Симеоновом речнику (Simeon, 1969) очигледна та појава, коју аутор решава тако што се код термина који има предност, наводи дефиниција, док се код осталих термина упућује на нормирани облик. Поред тих синонимних једночланих термина, у литератури се често употребљавају двочлане или вишечлане терминолошке синтагме, као што су: руска/рускословенска/чешка позајмленица, старочрквенословенска/ирквенословенска/ ирквеноруска/рускословенска/чешка реч или тексема односно тексика, реч ирквеноруског порекла, (позајмлена) реч из руског језика, лексика из ирквенословенског раздобль (Брборић, 1996; Матијашевић, 1996b; Стијовић, 1992; Skok, 1971-1974) и многе друге.

Хомонимни облици не заостају по бројности. Најизраженији пример је термин славенизам који може да означава реч преузету из словенских језика (Simeon, 1969; Матијашевић, 1996b), старословенског језика (Simeon, 1969), рускословенског (Радовић Тешић, 2009) и реч из периода славеносрпског књижевног језика, која је рускословенског и руског или српскословенског порекла. Фонетски лик са слов-, словенизам, односи се на реч преузету из словенских језика, рускословенског језика, словеначког језика и на реч из период славеносрпског језика.

Када је реч о дефинисању тих термина у речницима (ГЛП, 2011; ШРЈTП, 2003; ELSHJ, 1972; Simeon, 1969), можемо закључити да су дефиниције непрецизне и неуједначене. Уочава се то када се пореде све дефи-

26 Термин славизам преузет је од фр. slavisme (< срлат. Slavus „Словен”; Клајн $\&$ Шипка, 2008), док су словенизам и славенизам изведени од домаћих облика Словен односно Славен. 
ниције једног речника, што се види из горе изложеног материјала, али и кад се пореде дефиниције једног термина у свим речницима, нпр. дефиниција за термин русизам: „оsobine ruskog jezika u nekom drugom jeziku” (ELSHJ, 1972), „jezični element (riječ, izraz, konstrukcija) preuzet iz ruskoga jezika u koji drugi jezik” (Simeon, 1969), „реч или језичка конструкција преузета из руског језика или сачињена према том језику, а не слаже се са системом језика у коме је то сачињено” (ШРЈTП, 2003) и „позајмљеница, реч или израз из руског језика” (ГЛП, 2011).

Код те врсте термина важно је и узети у обзир међусловенско позајмљивање, јер су различитим (директним или индиректним) путевима речи могле стићи у српски језик, ${ }^{27}$ те је неопходно навести да ли се под тим термином подразумева и посредништво језика у трансферу речи.

Битно је и означити и разликовати лексику која је позајмљена из словенских језика у односу на лексику која је из општесловенске заједнице односно која припада словенском лексичком наслеђу (Матијашевић, 1996b, с. 156).

Енциклопедијски речници који су ексцерпирани у овом раду не региструју све термине. ${ }^{28}$ Р. Симеон (Simeon, 1969) наводи већину термина, заједно са детаљним дефиницијама и тумачењима, као и са еквивалентима из 7 језика, међутим речник из 1969. године је увелико застарео. Као и Симеонов речник, SSLT (1977-1979) представља значајно лексикографско дело у којем је наведен велики број термина за именовање лексике преузете из словенских језика, али се и за тај речник може констатовати да је изгубио на актуелности.

Поредећи српске термине са терминима у другим словенским језицима, на материјалу из SSLT, славистичке библиографске базе iSybislaw и електронских речника појединих словенских језика, можемо закључити да постоје дублетни фонетски и творбени ликови код именовања лексике преузете из словенских језика: 1) срп. славизам, хрв. slavizam, мак. славизам, слн. slavizem, пољ. slawizm, чеш. slavismus, slavism, слч. slavizmus, луж. slawizm; 2) срп. славенизам, буг. славянизбм, рус. славянизм, бел. славянізм; и 3) срп. словенизам, пољ. słowianizm, укр. слов’янізм.

27 На пример, руски језик је често био посредник за црквенословенизме и за речи из других словенских језика (Јанковић, 2017, с. 764; Матијашевић, 1996b, с. 157).

28 А. Милановић узима за пример термин славеносрбизам за који каже да не постоји ни у ELSHJ, ни код Simeona (о томе детаљније у Милановић, 2005, с. 324). 
Лексика чешког порекла се двојако обележава не само у српском и хрватском, него и у пољском (bohemizm/czechizm), руском (богемизм/ чехизм) и у лужичким језицима (bohemizm/čechizm). Исто је и са речима преузетим из хрватског језика: срп. кроатизам/хрватизам, слн. hrvatizem/ kroatizem, док је у осталим словенским језицима или са почетним $\kappa$ - (хрв., мак., чеш., слч., луж.) или са $x$ - (буг., пољ., рус., укр., бел.).

Фонетски блиски или формално исти ликови представљају проблем код разликовања термина, као у случају код именовања лексике из словеначког језика (бел. словянізм, срп. словенизам) у односу на лексику из словенских језика (бел. славянізм, срп. словенизам).

Y SSLT (1977-1979) нису регистровани термини у словенским језицима који би означавали лексику старословенског порекла, међутим јесу за лексику црквенословенског порекла. У питању су сложенице, у чијем саставу су термини за лексику словенског порекла: буг. славянизъм - ибрковнославянизъм, мак. славизам - ирковен славизам, слн. slavizem - cerkveni slavizem и тако у свим словенским језицима осим у српском и хрватском.

На основу ексцерпираног материјала и анализе српских и других словенских термина за именовање лексике преузете из словенских језика, долазимо до неколико закључака. Варирање термина огледа се у неуједначености форме термина и у семантичком садржају (синонимија и вишезначност унутар термина), те је сходно томе неопходна њихова стандардизација у будућем терминолошком речнику. Анализирани термини потичу из извора, који су објављени у дужем временском распону, од шездесетих година прошлог века до данас, те се на основу тога може закључити да су се термини са основом слов- (ирквенословенизам, српскословенизам, рускословенизам) усталили у србистици, док се са основом слав- подразумева искључиво термин славенизам, нормиран захваљујући А. Младеновићу.

Скраћенице

ГЛП - Радовић Тешић, М. (2011). Граматички и лингвистички појмовник. Београд: Учитељски факултет.

ELSHJ - Peco, A., Stanojčić, Ž. (1972). Enciklopedijski leksikon. Srpskohrvatski jezik. Beograd: Interpres.

Simeon - Simeon, R. (1969). Enciklopedijski rječnik lingvističkih naziva, I-II. Zagreb: Matica Hrvatska. 
SSLT - Jedlička, A. (red.) (1977-1979). Slovník slovanské lingvistické terminologie. Словарь славянской лингвистической терминологии. Dictionary of Slavonic linguistic terminology, 1-2. Praha: Academia.

ШРЈТП - Вуксановић, Ј. (2003). Школски речник језичких термина и појмова. Београд: Алтера.

\section{Извори и литература}

Ајдуковић, J. (1997). Русизми у српскохрватским речницима: Принципи адаптације: Речник. Фото Футура.

Ајдуковић, J. (1999). О дефиницији појма „русизам” на материјалу речника српског, македонског и бугарског језика. 3борник Матице српске за славистику, 56-57, 123-132.

Бјелаковић, И., Цветковић Теофиловић, И., \& Милановић, А. (Eds.). (2017). Речник славеносрпског језика: Огледна свеска. Матица српска.

Брборић, Б. (1996). Однос према туђицама: С мером или без аверзије. In J. Планкош (Ed.), О лексичким позајмљеницама (рр. 27-51). Градска библиотека Суботица; Институт за српски језик САНУ.

Вуксановић, J. (2003). Школски речник језичких термина и појмова [ШРЈТП]. Алтера.

Грицкат, И. (1963-1964). Вуков превод Новог завета као споменик великог филолошког настојања. Јужнословенски филолог, 26(1-2), 219-245.

Грицкат, И. (1969). Језик књижевности и књижевни језик - на основу српског писаног наслеђа из старијих епоха. Јужнословенски филолог, 28(1-2), 1-36.

Грицкат, И. (1985). Језичка анализа јужнословенских абагара. Јужнословенски билолог, 41, 35-64.

Дабић, Б. Л. (1981). Позајмљенице руског поријекла у српскохрватском језику. Кюижевни језик, 10, 7-25.

Дабић, Б. Л. (1984). Русизми и славјанизми у лексици Луче микрокозма. In J. Јерковић (Еd.), Лексикографија и лексикологија (рp. 47-52). Матица српска.

Дешић, М. П. (2017). Кроатизми у једнотомном рјечнику српског језика. In Р. Драгићевић (Ed.), Путевима речи (pp. 121-129). Филолошки факултет Универзитета у Београду.

Зорић, 3. (2013). Неколико речи о статусу и идентификацији славенизама. Зборник Матище српске за књижевност и језик, 61(3), 811-818.

Ивић, П., Клајн, И., Пешикан, М., \& Брборић, Б. (2004). Српски језички приручник. Београдска књига.

Јанковић, J. (n.d.). Табеле уз чланак: Варијантност лингвистичке терминологије у србистиии код именоваға лексике преузете из словенских језика. Academia. https:// isj-sanu.academia.edu/JelenaJanković/Conference-Presentations

Јанковић, J. (2017). Етимологија у часопису „Наш језик” [Dissertation, Филолошки факултет Универзитета у Београду]. https://www.academia.edu/35629921/Етимологија_у _часопису_Наш_језик_ 
Јанковић, J. (2019). Славенизми у Огледној свесци Речника славеносрпског језика. In С. Гудурић \& Б. РадићБојанић (Eds.), Језици и културе у времену и простору (Vol. 8/1, pp. 341-355). Универзитет у Новом Саду, Филозофски факултет. https://www.academia .edu/42075480/Славенизми_у_Огледној_свесци_Речника_славеносрпског_језика

Јовановић, В. (2017). Српска терминологија у Речнику словенске лингвистичке терминологије из угла савременог стања српске лингвистике. In П. Пипер \& В. Јовановић (Eds.), Словенска терминологија данас (pp. 253-265). Српска академија наука и уметности, Институт за српски језик САНУ.

Клајн, И., \& Шипка, М. (2008). Велики речник страних речи и израза. Прометеј.

Копривица, В. (2008). О бохемизмима у српском језику. Славистика, 12, 371-376.

Лома, А. (1999). Рефлекси групе n(ь)n у српској топонимији. Наш језик, 33(1-2), 99-105.

Маројевић, Р. (2002-2003). Реконструкција сугласника у критичком издању Горског вијенца. Наш језик, 34(3-4), 209-233.

Маројевић, Р. (2007). Пјеснички језик Његошев. І. Научни састанак слависта у Вукове дане, 36(1), 199-214.

Маројевић, Р. (2008). Пјеснички језик Његошев. II. Научни састанак слависта у Вукове дане, 37(1), 179-198.

Матијашевић, Ј. (1996а). Осврт на русизме послератних година. Научни састанак слависта у Вукове дане, 25(2), 367-376.

Матијашевић, J. (1996b). Словенске речи као стране речи у српском језику. In J. Планкош, О лексичким позајмљеницама (pp. 153-158). Градска библиотека Суботица; Институт за српски језик САНУ.

Милановић, А. (2003). Терминолошки проблеми у области историје српског књижевног језика. Научни састанак слависта у Вукове дане, 32(3), 295-304.

Милановић, А. (2004). Статус појма и термина посрбица. Научни састанак слависта у Вукове дане, 33(3), 245-252.

Милановић, А. (2005). Статус појма и термина славеносрбизам у србистици. Научни састанак слависта у Вукове дане, 34(3), 323-327.

Милановић, А. (2017). Развој српске терминолошке мисли у 19. веку: Допринос Лазе Костића. In П. Пипер \& В. Јовановић (Eds.), Словенска терминологија данас (pp. 317330). Српска академија наука и уметности.

Милановић, А. (2018). Обрада посрбица у Речнику славеносрпског језика. Научни састанак слависта у Вукове дане, 47(1), 231-239. https://doi.org/10.18485/msc.2018.47.1.ch22

Младеновић, А. (1989). Славеносрпски језик - студије и чланци. Књижевна заједница.

Младеновић, А. (2008). Историја српског језика. Чигоја штампа.

Оташевић, Ђ. (1997). Универбација. Наш језик, 32(1-2), 52-63.

Пешикан, М. (1985). Око часа и сата. Наш језик, 26(4-5), 273-275.

Пешикан, М., Јерковић, Ј., \& Пижурица, М. (2010). Правопис српскога језика. Матица српска.

Пипер, П. (1999). Уз нове дефиниције русизма. Зборник Матице српске за славистику, 56-57, 129-132. 
Радовић Тешић, М. (2009). С речима и речником. Учитељски факултет.

Радовић Тешић, М. (2011). Граматички и тингвистички појмовник [ГЛП]. Учитељски факултет.

Сикимић, Б. (1997). Четири тома Бугарског етимолошког речника. Јужнословенски филолог, 53, 244-247.

Станковић, Б. (1996). О положају црквенословенизама и русизама у српском књижевном језику. Научни састанак слависта у Вукове дане, 25(2), 377-384.

Стевановић, М. (1987). Вук у своме и нашем језику. Матица српска.

Стијовић, С. (1992). Славенизми у Његочевим песничким делима. Издавачка књижарница Зорана Стојановића.

Терзић, Б. (1999). Руско-српске језичке паралеле. Славистичко друштво Србије.

Терзић, Б. (2003). Осврт на русизме у савременом српском књижевном језику. Зборник Матице српске за славистику, 64, 205-216.

Тошовић, Б. (1981). Русизми у нашем публицистичком стилу. Кюижевни језик, 10(2), 35-42.

Ћорић, Б. (1991). О неким творбеним моделима са становишта језичке економије. Научни састанак слависта у Вукове дане, 20(2), 325-333.

Чигоја, Б. (1988). О Вуковим називима за раније типове нашег књижевног језика. Научни састанак слависта у Вукове дане, 17(2), 169-176.

Чигоја, Б. (2005). Славенизми - допринос Светозара Стијовића проучавању термина славенизам. Научни састанак слависта у Вукове дане, 34(3), 315-321.

Jedlička, A. (Ed.). (1977-1979). Slovník slovanské lingvistické terminologie / Словарь славянской лингвистической терминологии / Dictionary of Slavonic linguistic terminology [SSLT] (Vols. 1-2). Academia.

Peco, A., \& Stanojčić, Ž. (1972). Enciklopedijski leksikon: Srpskohrvatski jezik [ELSHJ]. Interpres.

Simeon, R. (1969). Enciklopedijski rječnik lingvističkih naziva (Vols. 1-2). Matica Hrvatska.

Skok, P. (1971-1974). Etimologijski rječnik hrvatskoga ili srpskoga jezika (Vols. 1-4). Jugoslavenska akademija znanosti i umjetnosti.

\section{Bibliography (Transliteration)}

Ajduković, J. (1997). Rusizmi u srpskohrvatskim rečnicima: Principi adaptacije: Rečnik. Foto Futura.

Ajduković, J. (1999). O definiciji pojma "rusizam" na materijalu rečnika srpskog, makedonskog i bugarskog jezika. Zbornik Matice srpske za slavistiku, 56-57, 123-132.

Bjelaković, I., Cvetković Teofilović, I., \& Milanović, A. (Eds.). (2017). Rečnik slavenosrpskog jezika: Ogledna sveska. Matica srpska. 
Brborić, B. (1996). Odnos prema tuđicama: S merom ili bez averzije. In J. Plankoš (Ed.), O leksičkim pozajmljenicama (pp. 27-51). Gradska biblioteka Subotica; Institut za srpski jezik SANU.

Čigoja, B. (1988). O Vukovim nazivima za ranije tipove našeg književnog jezika. Naučni sastanak slavista u Vukove dane, 17(2), 169-176.

Čigoja, B. (2005). Slavenizmi - doprinos Svetozara Stijovića proučavanju termina slavenizam. Naučni sastanak slavista u Vukove dane, 34(3), 315-321.

Ćorić, B. (1991). O nekim tvorbenim modelima sa stanovišta jezičke ekonomije. Naučni sastanak slavista u Vukove dane, 20(2), 325-333.

Dabić, B. L. (1981). Pozajmljenice ruskog porijekla u srpskohrvatskom jeziku. Književni jezik, 10, 7-25.

Dabić, B. L. (1984). Rusizmi i slavjanizmi u leksici Luče mikrokozma. In J. Jerković (Ed.), Leksikografija i leksikologija (pp. 47-52). Matica srpska.

Dešić, M. P. (2017). Kroatizmi u jednotomnom rječniku srpskog jezika. In R. Dragićević (Ed.), Putevima reči (pp. 121-129). Filološki fakultet Univerziteta u Beogradu.

Grickat, I. (1963-1964). Vukov prevod Novog zaveta kao spomenik velikog filološkog nastojanja. Južnoslovenski filolog, 26(1-2), 219-245.

Grickat, I. (1969). Jezik književnosti i književni jezik - na osnovu srpskog pisanog nasleđa iz starijih epoha. Južnoslovenski filolog, 28(1-2), 1-36.

Grickat, I. (1985). Jezička analiza južnoslovenskih abagara. Južnoslovenski filolog, 41, 35-64.

Ivić, P., Klajn, I., Pešikan, M., \& Brborić, B. (2004). Srpski jezički priručnik. Beogradska knjiga.

Janković, J. (n.d.). Tabele uz članak: Varijantnost lingvističke terminologije u srbistici kod imenovanja leksike preuzete iz slovenskih jezika. Academia. https://isj-sanu.academia.edu /JelenaJanković/Conference-Presentations

Janković, J. (2017). Etimologija u časopisu “Naš jezik” [Dissertation, Filološki fakultet Univerziteta u Beogradu].https://www.academia.edu/35629921/Етимологија_у_часопису_Наш_језик_

Janković, J. (2019). Slavenizmi u Oglednoj svesci Rečnika slavenosrpskog jezika. In S. Gudurić \& B. Radić-Bojanić (Eds.), Jezici i kulture u vremenu i prostoru (Vol. 8/1, pp. 341-355). Univerzitet u Novom Sadu, Filozofski fakultet. https://www.academia.edu/42075480/Славенизми _у_Огледној_свесци_Речника_славеносрпског_језика

Jedlička, A. (Ed.). (1977-1979). Slovník slovanské lingvistické terminologie / Slovar' slavianskoŭ lingvisticheskoŭ terminologii / Dictionary of Slavonic linguistic terminology [SSLT] (Vols. 1-2). Academia.

Jovanović, V. (2017). Srpska terminologija u Rečniku slovenske lingvističke terminologije iz ugla savremenog stanja srpske lingvistike. In P. Piper \& V. Jovanović (Eds.), Slovenska terminologija danas (pp. 253-265). Srpska akademija nauka i umetnosti, Institut za srpski jezik SANU.

Klajn, I., \& Šipka, M. (2008). Veliki rečnik stranih reči i izraza. Prometej.

Koprivica, V. (2008). O bohemizmima u srpskom jeziku. Slavistika, 12, 371-376.

Loma, A. (1999). Refleksi grupe n(ь)n u srpskoj toponimiji. Naš jezik, 33(1-2), 99-105.

Marojević, R. (2002-2003). Rekonstrukcija suglasnika u kritičkom izdanju Gorskog vijenca. Naš jezik, 34(3-4), 209-233. 
Marojević, R. (2007). Pjesnički jezik Njegošev. I. Naučni sastanak slavista u Vukove dane, 36(1), 199-214.

Marojević, R. (2008). Pjesnički jezik Njegošev. II. Naučni sastanak slavista u Vukove dane, 37(1), 179-198.

Matijašević, J. (1996a). Osvrt na rusizme posleratnih godina. Naučni sastanak slavista u Vukove dane, 25(2), 367-376.

Matijašević, J. (1996b). Slovenske reči kao strane reči u srpskom jeziku. In J. Plankoš (Ed.), O leksičkim pozajmljenicama (pp. 153-158). Gradska biblioteka Subotica; Institut za srpski jezik SANU.

Milanović, A. (2003). Terminološki problemi u oblasti istorije srpskog književnog jezika. Naučni sastanak slavista u Vukove dane, 32(3), 295-304.

Milanović, A. (2004). Status pojma i termina posrbica. Naučni sastanak slavista u Vukove dane, 33(3), 245-252.

Milanović, A. (2005). Status pojma i termina slavenosrbizam u srbistici. Naučni sastanak slavista u Vukove dane, 34(3), 323-327.

Milanović, A. (2017). Razvoj srpske terminološke misli u 19. veku: Doprinos Laze Kostića. In P. Piper \& V. Jovanović (Eds.), Slovenska terminologija danas (pp. 317-330). Srpska akademija nauka i umetnosti.

Milanović, A. (2018). Obrada posrbica u Rečniku slavenosrpskog jezika. Naučni sastanak slavista u Vukove dane, 47(1), 231-239. https://doi.org/10.18485/msc.2018.47.1.ch22

Mladenović, A. (1989). Slavenosrpski jezik - studije i članci. Književna zajednica.

Mladenović, A. (2008). Istorija srpskog jezika. Čigoja štampa.

Otašević, Đ. (1997). Univerbacija. Naš jezik, 32(1-2), 52-63.

Peco, A., \& Stanojčić, Ž. (1972). Enciklopedijski leksikon: Srpskohrvatski jezik [ELSHJ]. Interpres.

Pešikan, M. (1985). Oko časa i sata. Naš jezik, 26(4-5), 273-275.

Pešikan, M., Jerković, J., \& Pižurica, M. (2010). Pravopis srpskoga jezika. Matica srpska.

Piper, P. (1999). Uz nove definicije rusizma. Zbornik Matice srpske za slavistiku, 56-57, 129-132.

Radović Tešić, M. (2009). S rečima i rečnikom. Učiteljski fakultet.

Radović Tešić, M. (2011). Gramatički i lingvistički pojmovnik [GLP]. Učiteljski fakultet.

Sikimić, B. (1997). Četiri toma Bugarskog etimološkog rečnika. Južnoslovenski filolog, 53, 244-247.

Simeon, R. (1969). Enciklopedijski rječnik lingvističkih naziva (Vols. 1-2). Matica Hrvatska.

Skok, P. (1971-1974). Etimologijski rječnik hrvatskoga ili srpskoga jezika (Vols. 1-4). Jugoslavenska akademija znanosti i umjetnosti.

Stanković, B. (1996). O položaju crkvenoslovenizama i rusizama u srpskom književnom jeziku. Naučni sastanak slavista u Vukove dane, 25(2), 377-384.

Stevanović, M. (1987). Vuk u svome i našem jeziku. Matica srpska.

Stijović, S. (1992). Slavenizmi u Njegoševim pesničkim delima. Izdavačka knjižarnica Zorana Stojanovića. 
Terzić, B. (1999). Rusko-srpske jezičke paralele. Slavističko društvo Srbije.

Terzić, B. (2003). Osvrt na rusizme u savremenom srpskom književnom jeziku. Zbornik Matice srpske za slavistiku, 64, 205-216.

Tošović, B. (1981). Rusizmi u našem publicističkom stilu. Književni jezik, 10(2), 35-42.

Vuksanović, J. (2003). Školski rečnik jezičkih termina i pojmova [ŠRJTP]. Altera.

Zorić, Z. (2013). Nekoliko reči o statusu i identifikaciji slavenizama. Zbornik Matice srpske za književnost i jezik, 61(3), 811-818.

\section{Variance of Serbian Linguistic Terms for Naming Lexemes Borrowed from Slavic Languages}

\section{Summary}

This article provides an overview of Serbian linguistic terms for naming lexemes borrowed from Slavic languages. The terms were extracted from the reference linguistic sources in which they are mentioned, such as encyclopedic dictionaries of the linguistic terminology of the Serbian language and the latest Правопис српскога језика [Orthographic Rules of the Serbian Language], and from previous Serbian literature, such as monographs, studies and articles by various Serbian linguists. Considering the entire extracted material, the study notes terminological problems concerning the variance and inconsistency of linguistic terms in this area. It also makes a comparison with linguistic terms in other Slavic languages, based on the material from the Dictionary of Slavonic Linguistic Terminology and the Slavic Bibliographic Database iSybislaw. 


\section{Wariantywność serbskich terminów językoznawczych na określenie leksemów zapożyczonych z języków słowiańskich}

\section{Streszczenie}

Niniejszy artykuł przedstawia serbskie terminy językoznawcze określające leksemy zapożyczone z języków słowiańskich. Omawiane terminy pochodzą ze źródeł językoznawczych, w których się pojawiają, takich jak encyklopedyczne słowniki serbskiej terminologii językoznawczej czy najnowszy Правопис српскога језика [Zasady ortograficzne języka serbskiego], oraz z serbskiej literatury przedmiotu, np. monografii, studiów i artykułów serbskich językoznawców. W odniesieniu do całości analizowanego materiału, opracowanie zwraca uwagę na problemy terminologiczne związane $\mathrm{z}$ wariantywnością i niespójnością terminów językoznawczych w tym zakresie. Dokonuje również porównania $\mathrm{z}$ terminami w innych językach słowiańskich na podstawie materiału ze słownika pod redakcją Aloisa Jedlički (Slovník slovanské lingvistické terminologie I Словарь славянской лингвистической терминологии / Dictionary of Slavonic Linguistic Terminology) oraz bibliograficznej bazy danych iSybislaw.

Keywords: Serbian language; Slavic languages; linguistic terminology; lexemes borrowed from Slavic languages

Słowa kluczowe: język serbski; języki słowiańskie; terminologia językoznawcza; leksemy zapożyczone z języków słowiańskich

Jelena Dragoslav Janković, Institute for the Serbian Language, Serbian Academy of Sciences and Arts, Belgrade, Serbia

ORCID: https://orcid.org/0000-0002-7990-3813

Correspondence: enanikolic11@yahoo.com

The preparation of this article was self-financed by the author.

Competing interests: The author has declared that she has no competing interests.

Publication history: Received: 2020-11-19; Accepted: 2021-07-13; Published: 2021-12-31 